This is the peer reviewed version of the following article: Mahrukh Doctor; Brazilian business and Itamaraty in the PT era: foreign policy-making in the context of 'graduation dilemmas', International Affairs, Volume 93, Issue 3, 1 May 2017, Pages 643-660, which has been published in final form at https://doi.org/10.1093/ia/iix077. This article may be used for non-commercial purposes in accordance With Wiley Terms and Conditions for selfarchiving.

\title{
Brazilian business and Itamaraty in the PT era: foreign policy-making in the context of graduation dilemmas
}

\author{
Mahrukh Doctor \\ (to be published in International Affairs, forthcoming May 2017)
}

International attention to Brazil has mainly focused on the country's rising profile as an emergent power on the global stage, but it is the domestic dimensions of this rise that increasingly preoccupy informed opinion in Brazil. ${ }^{1}$ The evolution of opinions and actions in Brazil in the past decade indicates marked change both in the attitude of Brazilian civil society towards foreign policy and in foreign policy-makers' receptiveness to civil society inputs into foreign policy debates. Specifically, President Luiz Inácio Lula da Silva (2003-10) of the Workers’ Party (Partido dos Trabalhadores, PT) took the reliance on presidential diplomacy to unprecedented levels, ${ }^{2}$ but at the same time signalled the importance of including societal inputs into external relations. To this end, he created the post of special adviser on international affairs (SAIA) within the office of the presidency. The holder of this office was expected to act alongside the ministry of external relations, traditionally referred to as Itamaraty. Whereas the special adviser's role was focused on addressing cross-border relations with civil society actors - trade unions, non-governmental organizations (NGOs), social movements and other groups - in the global South, Itamaraty continued to handle the formal and more traditional forms of interstate and multilateral relations, but with a growing openness to

\footnotetext{
${ }^{1}$ See Jeffrey Needell, ed., Emergent Brazil: key perspectives on a new global power (Gainesville: University Press of Florida, 2015); Oliver Stuenkel and Matthew Taylor, eds, Brazil on the global stage: power, ideas and the liberal international order (New York: Palgrave Macmillan, 2015).

${ }^{2}$ See Andres Malamud, 'Presidentialist decision making in Latin American foreign policy: examples from regional integration processes', in Jorge Domínguez and Ana Covarrubias, eds, Routledge handbook of Latin America in the world (London and New York: Routledge, 2014), pp. 112-23; Sean Burges, Brazilian foreign policy after the Cold War (Gainesville: University Press of Florida, 2009), esp. pp. 158-84; Jeffrey Cason and Timothy Power, 'Presidentialization, pluralization and the rollback of the Itamaraty: explaining change in Brazilian foreign policy’, International Political Science Review 30: 2, 2009, pp. 117-40.
} 
societal inputs. Lula's successor as president, Dilma Rousseff (2011-16), also of the PT, maintained the two-tier foreign policy-making structure.

In this context it becomes interesting to investigate the changing role of business in foreign policy-making in the course of Brazil's increasing integration into the global economy during the PT years (and beyond). Amorim and Malamud argue in their comparative study of Latin American foreign policy from 1946 to 2008 that Brazilian foreign policy was a complex blend of systemic and domestic determinants, but with a prevalence of 'realist systemic variables' ${ }^{3}$ The three domestic factors that they identify as being particularly relevant are institutional, ideological and bureaucratic —all factors strongly associated with the state (or at least the government). This article agrees with their overall analysis. However, it also argues that as democracy was consolidated in Brazil, another key domestic factor was the growing influence of societal actors in the foreign policy-making process and foreign policy decisions. As one prominent scholar of Brazilian foreign policy notes, the 'plurality, diversity and heterogeneity of actors and agendas that directly or indirectly take part in foreign affairs are perhaps the most impressive feature of Brazil's new face to the world'. ${ }^{4}$

The growing role of societal actors in a broadening range of policy areas is unsurprising in the context of democratization. The challenge for policy-makers was mainly around the issue of how to involve societal actors in developing foreign policy agendas and actions that were seen as legitimate but did not hamper the coherence of diplomatic activity. ${ }^{5}$ Thus, the article examines two questions: first, why did Brazil's push for emerging power status see foreign policy-makers involving civil society in the quest to achieve their global ambitions? And second, why did foreign policy preferences shift in

${ }^{3}$ Octavio Amorim and Andres Malamud, 'What determines foreign policy in Latin America? Systemic versus domestic factors in Argentina, Brazil and Mexico, 19462008', Latin American Politics and Society 57:4, 2015, pp. 1-27.

${ }^{4}$ Maria Regina Soares de Lima, 'The cartography of Brazil in the world', in Carlos Milani, Enara Echart Munoz, Rubens Duarte and Magno Klein, Atlas of Brazilian foreign policy (Buenos Aires and Rio de Janeiro: Consejo Latinoamericano de Ciencias Sociales (CLACSO) and Editora de Universidade do Estado de Rio de Janeiro (EdUERJ), 2016), p. 1.

${ }^{5}$ Pia Riggirozzi and Jean Grugel, 'Regional governance and legitimacy in Latin America: the meaning of UNASUR', International Affairs 91: 4, July 2015, pp. 781-97. 
the PT years, and to what extent did this change the level of influence of different societal actors? Borrowing from Milani, Pinheiro and Lima's concept of the 'graduation dilemma' (as explained in their article in the special themed section of this issue of the journal), ${ }^{6}$ the analysis is based on a view of graduation not as an outcome but as a process. I argue that even though Brazil's overall foreign policy goals did not change during the PT years, the country faced numerous graduation dilemmas, which raised contradictory expectations in international and domestic audiences. This required adjustments in its foreign policy actions and preferences as well as in the scope of involvement of societal actors in foreign policy decisions. The analysis also shows why shifting policy preferences (both pragmatic and ideological) changed the mix of societal influence.

Two bodies of academic literature provided the background to the analysis developed in this article. First, the internationalization and domestic politics theories developed by Keohane and Milner ${ }^{7}$ with a group of other scholars shaped my interest in examining the political impacts of internationalization of national markets on domestic actors' policy preferences, especially their foreign economic policy agendas, decisions and institutions. This literature indicates not only how internationalization generates new domestic coalitions around differential effects of increased openness, but also how it might affect the autonomy of government policy choices. ${ }^{8}$ Second, the analysis contributes to the power transition literature, ${ }^{9}$ including its adaptation, extension and refinement as proposed in the articles in this special section. At the forefront lies an interest, shared with other authors in this group of articles, in developing a more nuanced analysis that goes beyond states that challenge for primacy to include second-

${ }^{6}$ Carlos R. S. Milani, Leticia Pinheiro and Maria Regina Soares de Lima, ‘Brazil’s foreign policy and the graduation dilemma’, , International Affairs 93: 3, May 2017, pp. 000-00 above. (page numbers not available yet)

${ }^{7}$ See the chapters in Robert Keohane and Helen Milner, eds, Internationalization and domestic politics (Cambridge: Cambridge University Press, 1996).

${ }^{8}$ Keohane and Milner, eds, Internationalization and domestic politics.

${ }^{9}$ See Ronald Tammon, 'The Organski legacy: a fifty-year research program', International Interactions 34: 4, 2008, pp. 314-32; Richard Lebow and Benjamin Valentino, 'Lost in transition: a critical analysis of power transition theory', International Relations 23: 3, 2009, pp. 389-410. 
tier states (especially non-nuclear powers) in the process of building international order scenarios and contributing to global governance. ${ }^{10}$

The main sources for my research are interviews, speeches and writings of key businesspeople and diplomats along with official documents in the economic policy areas that relate to external relations. The analysis is presented in four parts. First, I note some of Brazil's graduation dilemmas, involving both state and societal actors. Second, I examine how business actors organized themselves to represent their interests to PT governments and how they viewed their role in Brazilian foreign policy-making. Next, the analysis considers Itamaraty's responses to collective action by business, with particular emphasis on why state actors' responses changed over time. The concluding section discusses why shifting economic conditions and policy preferences changed the level of societal, especially business, influence on foreign policy in the PT years.

\section{Brazil's graduation dilemmas}

Brazilian policy-makers face a number of practical dilemmas related to the country's rising influence in the global arena. The first—and the core-dilemma is this: is Brazil really ready to lose its status as a developing country (an implicit aspect of graduation)? Given its rising level of development and its consolidated status as a middle-income economy, it has already lost access to a variety of official sources of development assistance. For example, Brazil was removed from the list of beneficiaries under the Generalized System of Preferences in trade with the EU in 2014 and with Canada in 2015. ${ }^{11}$ The EU dropped Brazil on the basis of revised rules in its Regulation 978/2012, which specified withdrawal of the scheme's benefits if the World Bank ranked an economy in the high-income or upper-middle-income category in each of the previous three years. ${ }^{12}$ It was only a matter of time before graduation would see Brazil's partners

\footnotetext{
${ }^{10}$ See also Andrew Hurrell, On global order: power, values and the constitution of international society (Oxford: Oxford University Press, 2007).

${ }^{11}$ UNCTAD, Generalised System of Preferences: list of beneficiaries (Geneva: United Nations Press, 2015).

${ }^{12}$ See European Commission, 'EU publishes revised preferential import scheme for developing countries'; www.trade.ec.europa.en/doclib/press/index.cfml?id=840, 31
} October 2012 . (Unless otherwise noted at point of citation, all URLs cited in this article were accessible on 21 March 2017.) 
in the global South questioning its continuing credentials to speak in the name of developing countries. Certainly, its claims to emerging power status were increasingly incompatible with use of a discourse of the weak in the international arena.

A second and more urgent dilemma is: can Brazil afford to pay the costs of graduation? PT governments understood that recognition as a global or regional power implied taking on the costs of leadership. Critics often question Brazil's willingness to sustain a consistent 'diplomacy of generosity' and its ability to afford the organizational and system-management costs typically assumed by leaders. Others caution that Brazil needs to avoid becoming a prisoner of its followers' expectations, a tendency that has already required Brazil to yield on points that were not in its self-interest in both World Trade Organization (WTO) negotiations and regional relations. ${ }^{13}$ Thus, for example, both business associations and labour unions have expressed some disquiet over Brazil's acceptance of duty-free, quota-free imports from least developed countries as agreed at the WTO’s Bali ministerial in 2013. ${ }^{14}$ There were also many expressions of dissatisfaction in some groups of society with the so-called 'strategic patience' of PT governments towards Argentina's actions in regional economic relations. Whereas the government argued that it was demonstrating regional crisis management capabilities and leadership, ${ }^{15}$ opponents doubted that this stance was in Brazil’s longer-term national interest.

The third dilemma, and the particular focus of this article, is this: how can foreign policy-makers build support for graduation and a shared vision within Brazilian society for the country's role in the international arena? This last dilemma relates to the difficulties foreign policy-makers and diplomats face in fostering favourable public opinion and civil society support, surely vital in a democracy. It has stimulated discussions on whether foreign policy should be viewed as just another public policy or

\footnotetext{
${ }^{13}$ Charalampos Efstathopolous, 'Leadership in the WTO: Brazil, India and the Doha development agenda', Cambridge Review of International Affairs 25: 2, 2012, pp. 26993.

${ }^{14}$ Sandra Rios and Fernando Panzini, Pacote de Bali, CINDES Breves no. 82, Rio de Janeiro: Centro de Estudos de Integração e Desenvolvimento, March 2014.

${ }^{15}$ Maria Regina Soares de Lima and Monica Hirst, 'Brazil as an intermediate state and regional power: action, choice and responsibilities', International Affairs 82: 1, Jan.
} 2006, pp. 21-40. 
something more, ${ }^{16}$ and how to involve societal actors in Brazil's rise. By bringing societal actors into the foreign policy equation, state actors hoped to assure an active engagement with the PT's project for increasing Brazil's influence in international affairs.

It is within this dilemma that the answer to the first research question is located. As will be shown, domestic actors not only conditioned Brazil's rise, but also expected to shape it. To further flesh out the answer, my research focuses on business, which is one of the groups most active in foreign policy, and one that benefits from consistent access to the elitist circles of Itamaraty where foreign policy is still typically made. As such, the article's focus is on foreign economic policy, specifically trade policy, although business has made its views known on a range of other foreign policy issues (e.g. the human rights and political aspects of the PT's relations with Cuba, Venezuela and even Iran). In addition, the analysis explains why business influence waxed and waned relative to that of other societal actors during the PT years.

\section{Business foreign policy interests}

Brazil has long been a relatively closed economy, with foreign trade typically not exceeding 25 per cent of gross domestic product. ${ }^{17}$ Its economic development and industrialization in the twentieth century took place behind protectionist barriers and with heavy state intervention in the economy. ${ }^{18}$ This inwardly oriented path to growth and development meant that business rarely ventured into the realm of foreign policy-

\footnotetext{
${ }^{16}$ See e.g. the discussion in Monica Salomón and Leticia Pinheiro, 'Análise de politica externa e politica externa brasieira: trajetória, desafios e possibilidades de um campo de estudos’, Revista Brasileira de Politica Internacional 56: 1, 2013, pp. 40-59.

${ }^{17}$ World Bank, Trade as percentage of GDP: Brazil, 2016 www.data.worldbank.org/indicator/NE.TRD.GNFS.ZS?locations=BR. ${ }^{18}$ There is an extensive literature on these aspects of Brazilian economic policy. See e.g. Edmund Amann and Werner Baer, 'From developmental to regulatory state: the transformation of the government's impact on the Brazilian economy', Quarterly Review of Economics and Finance 45:2-3, 2005, pp. 421-31. Luiz Carlos Bresser Pereira, Developing Brazil: overcoming the failure of the Washington Consensus (Boulder: Lynne Rienner, 2009); Werner Baer, The Brazilian economy: growth and development, 7th edn (Boulder: Lynn Rienner, 2014).
} 
making. The trade opening policies of the 1990s gradually forced business to restructure, modernize and look beyond the domestic market to better appreciate external markets as a source of both import competition and export opportunity. The structural transformation of the economy challenged past protectionist preferences and the defensive stances taken in trade negotiations. ${ }^{19}$ It also gave businesses a significant stake in the evolution of trade policy and encouraged them to look beyond their usual interlocutors in the state. As part of this process, they turned their attention to the ministry of external relations, Itamaraty.

Business views and actions in respect of foreign policy most often centred on trade issues, mainly at the regional level, even before the PT was elected into government. ${ }^{20}$ However, it must be emphasized that business did not have a single position, nor did business associations rely exclusively on Itamaraty to represent their foreign policy interests and trade policy preferences. Unsurprisingly, business preferences often reflected their situation in respect of global competitiveness. Typically, industrialists (including many of the multinational corporations operating in Brazil) adopted more defensive or protection-seeking positions, agribusiness took more offensive and market-access focused positions, and the service sector was mainly domestically oriented. This situation remained more or less unchanged both before and during the years of PT government. How, then, did business seek to influence foreign economic policy, especially trade policy, during the PT years from 2003 to mid-2016? Industrialists were most likely to express their concerns about trade policy to ministers and bureaucrats in the ministry of development, industry and trade and the federal revenue department, but increasingly also to Itamaraty trade negotiators. Until recently,

${ }^{19}$ Pedro da Motta Veiga, ‘Brazil’s trade policy: moving away from old paradigms?’, in Lael Brainard and Leonardo Martinez-Dias, eds, Brazil as an economic superpower? Understanding Brazil's changing role in the global economy (Washington DC: Brookings Institution Press, 2012), pp. 113-36; Peter Kingstone, Crafting coalitions for reform: business preferences, political institutions, and neo-liberalism in Brazil (University Park, PA: Penn State University Press, 1999).

${ }^{20}$ Laura Gomez Mera, Power and regionalism in Latin America: the politics of Mercosur (Notre Dame, IN: University of Notre Dame Press, 2013); Marc Schelhase, Globalization, regionalization and business: conflict, convergence and influence (Basingstoke: Palgrave Macmillan, 2008). 
they expected the government and diplomats to defend their often protectionist interests. Definitive signs of change first appeared in demands made in 2010 by the National Confederation of Industry (CNI) for policies to support increasing Brazil's participation in international trade in manufactured goods, especially greater integration into global production chains. The CNI clearly stated its policy priorities, both domestically (addressing systemic competitiveness issues) and abroad (export promotion, stable access to foreign markets, and a new institutional framework for foreign trade and trade negotiations). ${ }^{21}$ Midway through President Dilma Rousseff's first mandate, a range of business association documents and industrialists' statements show a step change in their attitude towards foreign trade. They began demanding a more competition-oriented integration into the world economy. The most important state-level association, the Federation of Industries of the State of São Paulo (FIESP), argued that 'articulating a trade negotiation strategy that encourages Brazil's insertion into international commerce and high-value supply chains is an urgent matter'. ${ }^{22}$

Meanwhile, right from the start of the PT years in government, agribusiness worked closely with trade negotiators to push for better market access for Brazilian products and reduced state support for the agricultural sector in advanced economies. ${ }^{23}$ Agribusiness made concerted efforts to inform Brazil's positions in the WTO as well as in regional negotiations with the EU and for a Free Trade Area of the Americas. Agribusiness also used the National Confederation of Agriculture and Livestock (CNA) and legislators connected to the sector (the bancada ruralista) to represent their trade policy preferences to government. In contrast, the externally most active service sector in Brazil, the construction and engineering companies (empreteiras), were more likely to rely individually on presidential diplomacy to support their activities abroad as well as access to public bank credits to fund their foreign investments. It is in this context that the Brazilian Development Bank emerged as a formidable instrument of foreign

${ }^{21}$ CNI, A indústria e o Brasil: uma agenda para crescer mais e melhor (Brasília, 2010), esp. pp. 177-96.

${ }^{22}$ FIESP, Proposals for the external integration of industry: position paper (São Paulo, 2014), p. 1.

${ }^{23}$ Kirsten Hopewell, 'New protagonists in global economic governance: Brazilian agribusiness at the WTO’, New Political Economy 18: 4, 2013, pp. 603-23. 
policy. ${ }^{24}$ The empreteiras tended to have minimal interaction with diplomats in Brasília. Instead, interviewees suggested that these firms were more likely to share business intelligence and on-the-ground experience with an embassy’s commercial attachés stationed abroad.

Keeping in mind that there are many nuances and exceptions to this general picture of business's preferred interlocutors in the state, the analysis here examines how industrialists and agribusiness represented their foreign policy interests and preferences specifically to Itamaraty during the PT years. Business organized itself at the national, subnational and sectoral levels. Business entities at all levels overhauled their organizational structures in the 1990s in the aftermath of economic stabilization and market-oriented reforms. ${ }^{25}$ As part of their restructuring process, they typically increased the resources available to their foreign trade departments, which were now asked to deal with three areas of trade policy on a continuous basis: trade promotion, trade negotiations and trade remedies.

As early as 1996, the CNI had taken the lead in hosting the Brazilian Business Coalition (Coalizão Empresarial Brasileira, CEB), which coordinated business input into multilateral and regional trade negotiations. Alongside the CEB, a number of state federations of industry set up in-house trade policy councils, such as the Business Council for International Relations (Conselho Empresarial de Relações Internacionais, CERI) of the Federation of Industries of the State of Rio de Janeiro (FIRJAN) and the Superior Council on Foreign Trade (Conselho Superior de Comercio Exterior, COSCEX) of FIESP. Interestingly, these councils were often led by retired diplomats, such as Ambassadors Luiz Felipe Seixas Correa at CERI and Rubens Barbosa at COSCEX. Sectoral associations, such as the Brazilian Association of Exporters (AEB),

${ }^{24}$ Kathryn Hochstetler and Alfred Montero, 'The renewed developmental state: the national developmental bank and the Brazil model', Journal of Development Studies 49: 11, 2013, pp. 1484-99; Mahrukh Doctor, 'Assessing the changing roles of the Brazilian Development Bank’, Bulletin of Latin American Research 34: 2, 2015, pp. 197-213. ${ }^{25}$ Wagner Mancuso, 'Lobbying to reduce the "Brazil cost": the political strategies of Brazilian entrepreneurs', in José Carlos Marques and Peter Utting, eds, Business, politics and public policy (Basingstoke: Palgrave Macmillan, 2010), pp. 242-70; Mahrukh Doctor, Business-State relations in Brazil: Challenges of the port reform lobby (New York: Routledge, 2017) \{?\} 
the Brazilian Sugarcane Industry Association (UNICA) and the Brazilian Association of Vehicle Manufacturers (ANFAVEA), also engaged in extensive activities geared towards influencing foreign economic policy at both regional and global levels. For example, ANFAVEA was closely involved in discussions around the formation and revision of the automotive sector regime within the Southern Common Market (MERCOSUR) as well as with other trade partners such as Mexico.

Business financed think-tanks with highly technical and technocratic agendas, which conducted research and knowledge exchange activities involving public and private sector actors. Perhaps the best known of these is the Institute for International Trade Negotiations (ICONE), founded in 2003. It played a central role in informing Brazilian trade negotiators' positions in the run-up to the Cancún ministerial in 2003, and subsequent Brazilian positions on agricultural matters in the Doha Development Round (DDR). It also provided much of the technical input for the trade G20's proposals and positions in the DDR. ${ }^{26}$ Also, agribusiness entities provided the technical information that allowed Itamaraty to request WTO dispute settlement panels against the EU (in respect of sugar) and United States (for cotton). As state actors' reliance on information provided by societal actors increased, so opportunities increased for the latter to build up their political influence and policy impact.

Business also was involved in highly personalized exchanges with the PT governments on issues of foreign economic policy. For example, interviewees at FIESP mentioned that various senior officials and politicians felt 'at home' with them; these included President Lula, who often received visiting foreign dignitaries and delegations at the headquarters of FIESP in São Paulo (I was told this happened about twelve times in his eight years in office). Similarly, interviewees mentioned that Brazilian foreign ministers and WTO representatives often 'stopped by' at FIESP headquarters on their way to and from important international meetings such as the World Economic Forum in Davos and the various WTO ministerial conferences.

Thus, a plethora of business associations were in continuous contact with Itamaraty and other state actors. They monitored progress at policy and regulatory level as well as in

\footnotetext{
${ }^{26}$ See Pedro de Motta Veiga, Brazil and the G-20 group of developing countries in the WTO, Managing the Challenges of WTO Participation, case study no. 7 (Geneva: WTO, 2007); Hopewell, 'New protagonists'. For ICONE, see www.iconebrasil.com.br/theinstitute.
} 
international negotiations. They also kept their own members informed about foreign policy issues, both by publishing monthly online bulletins and research reports for their members (often on new regulations and likely impacts of policy changes) and by organizing seminars (often on technical matters) and conferences (often involving policy-makers as well as business representatives). For example, the AEB has held the annual National Exporters Meeting (Encontro Nacional de Exportadores) for 35 consecutive years.

In addition to the symbiotic relationship based on knowledge-sharing between businesspeople and diplomats, there was also a notable difference in business's relations with Itamaraty compared to its relations with other ministries. Typically, interactions between business interests and Itamaraty were highly elitist and very technically focused, rarely involving the wheeling and dealing seen elsewhere. Traditionally, business viewed Itamaraty as a pocket of bureaucratic excellence, although this view changed sharply in the latter half of the PT years, with business bitterly accusing the government of politicization of foreign policy-making. Moreover, Itamaraty did not have any real financial resources (credits or contracts) to distribute, which protected it from the struggle for advantage that other ministries were more likely to face. Finally, as PT governments sought to expand the size of Itamaraty (by 2010, Brazil had become one of the few states to have diplomatic relations with all members of the UN) and increase the diversity of the intake of the Rio Branco Institute (the school for diplomats), it was not unusual to see staff from business federations joining Itamaraty or external relations departments of other ministries. Ambitious younger staff at the foreign relations/trade departments of business entities were often well placed to pass competitive entrance examinations to take up civil service jobs in ministries dealing with trade policy related issues, including Itamaraty. Needless to say, these new recruits were familiar with business concerns and often maintained close ties with their former colleagues.

In general, business was reasonably happy with policy decisions made in the first half of the PT's 13-year tenure of the presidency. Initially, Lula's commitment to improving South-South ties boosted Brazil's trade performance more than could have been predicted (most notably with China). Of course, there were always some disagreements between PT governments and business on economic policy issues related to external relations and the international arena, but these were manageable. Clearly, business was satisfied with its ample access to the highest levels of policy-making during the initial 
Lula years. However, after the global financial crisis in 2008-2009, this apparent accommodation started turning sour.

Initially hard hit by the global credit crunch, business took the view that the much lauded trade surpluses of the previous years had been a function of external demand during the commodity boom, and had little to do with domestic policy choices. Soon, what started out as grumblings about deindustrialization, uncompetitive manufacturing exports and minimal production integration at the global and regional levels gradually ballooned into robust criticism of a 'self-imposed isolation' via non-participation in bilateral and biregional trade negotiations. Thus, as well as being dissatisfied with slowing growth, business became ever more disgruntled with poor results in multilateral and biregional trade negotiations, frustrated with the politicization of relations within MERCOSUR, ${ }^{27}$ and worried about increasing competition from Chinese exports at home and abroad.

These concerns and frustrations lie at the heart of business's changing posture towards the government in general and Itamaraty in particular. Initially, the brunt of criticism fell on poor policy implementation, well expressed by Rubens Barbosa, the president of COSCEX: there was 'no point [in FIESP] preparing studies, if the government-which does not have a long-term vision—does not help [with implementation] . . . there is no way that the private sector can do it all alone'. ${ }^{28}$ Soon practical complaints about industrial and trade policy issues took on a more politicized tone, with business openly denigrating what it considered to be the ‘ideologization’ of foreign policy. The PT government's loudly proclaimed emphasis on South-South ties came in for specific criticism. Business, especially industrialists, argued that the PT’s increasingly ideological and interventionist approach to economic policy had excluded Brazil from the emerging patterns of global trade and investment flows (often involving the North).

\footnotetext{
${ }^{27}$ See Mahrukh Doctor, 'Prospects for deepening Mercosur integration: economic asymmetry and institutional deficits', Review of International Political Economy 20: 3, 2013, pp. 515-40.

${ }^{28}$ Rubens Barbosa, ‘Agronegocio e setor energético podem ser saída para o Mercosul’, cited in Agencia Indusnet Fiesp, 16 June 2015,
}

http://www.fiesp.com.br/noticias/agronegocio-e-setor-energetico-podem-ser-saidas- 
They were particularly dissatisfied with foreign economic policies during Dilma Rousseff's period in office (January 2011 to May 2016).

Analysis of the articles and speeches of top businesspeople reveals that they rapidly and increasingly became disenchanted with and resentful of the PT government's 'strategic patience' with regional partners (for which read Argentina), ${ }^{29}$ policy accommodation with Brazil's followers in the South, ${ }^{30}$ and weak strategy for dealing with China (something that Lula's foreign minister, Celso Amorim, ${ }^{31}$ himself admitted could have been better handled). They even expressed their irritation with the perceived dilution of Itamaraty's influence over foreign policy, and began vocally to demand a 'foreign policy of results' ${ }^{32}$ Among the top demands (sometimes articulated in rather strident terms) were calls for the government to be more active in negotiating preferential trade agreements (PTAs) with important trade partners, without abandoning the priority given to multilateralism. These demands were often articulated alongside calls for more flexible relations with MERCOSUR, which from the business point of view meant either downgrading the customs union to a free trade agreement or allowing a 'dual velocity’ approach to negotiating extraregional PTAs. Business harshly castigated and blamed PT foreign policy-makers for Brazil’s exclusion from the mega trade and investment accords, like the Trans-Pacific Partnership and the Transatlantic Trade and Investment Partnership, being negotiated around the world. Another key (but relatively new) demand related to the urgency of assimilating the regulatory transformations occurring in global trade flows into domestic policy frameworks. Business wanted state actors to act in anticipation of a hoped-for eventual integration of Brazilian production into global value chains and/or WTO-plus or WTO-extra agreements.

\footnotetext{
29 'Strategic patience runs out', The Economist, 14 Dec. 2013.

${ }^{30}$ Efstathopolous, 'Leadership in the WTO'; Mahrukh Doctor, 'Brazil’s role in institutions of global economic governance: the WTO and G20', Global Society 9: 3, 2015, pp. 286-300.

${ }^{31}$ Celso Amorim, 'Brazilian foreign policy under President Lula (2003-2010): an overview’, Revista Brasileira de Politica Internacional, 53: special issue (An
} Assessment of the Lula Era), 2010, pp. 214-40.

32 Rubens Barbosa, ‘Por uma politica externa de resultados’, Estadão, 9 Sept. 2014, http://opiniao.estadao.com.br/noticias/geral,por-uma-politica-externa-de-resultadosimp-,1557082 
Finally, it is worth calling attention to a notable subtext in business's growing criticism of foreign policy actions during the PT era, especially during the Rousseff presidency. Reading between the lines, it is clear that business was not only disgruntled with low growth, ineffective policy and insufficient engagement with global value chains, but also increasingly resentful of the growing inclusion and influence of other societal actors in foreign policy-making circles. This underlying elitist attitude was most obvious in the way that business as well as opposition politicians repeatedly described policy decisions in the PT years as the 'politicization' of foreign policy. Their criticisms seemed to suggest that business preferences were apolitical (apparently in contrast to those of other civil society actors), or that there was an objective national interest (beyond some minimum of state security and survival) to which all civil society actors could subscribe.

To summarize, the analysis presented in this section provides answers to the first research question. It suggests a number of reasons why societal actors, specifically business interests, became increasingly involved in policy-making. It also discusses the various means business used to organize and represent its interests and views to state actors, especially Itamaraty.

\section{Itamaraty responses}

In many ways Itamaraty considered itself on the margins of collective efforts by business interests to influence policy. This, at least, was the traditional situation. From a diplomat's perspective, business barely took any notice of Itamaraty in the days of protectionism and inwardly oriented development. However, according to interviews with diplomats, economic liberalization and trade opening policies in the 1990s forced business to take note of the opportunities in and threats from external markets. Business began to take an interest in influencing first regional integration policies, and subsequently multilateral trade negotiations. It is in this context that Itamaraty became a target of Brazilian industrial and trade policy lobbying-something for which it initially was not prepared. Itamaraty diplomats saw themselves as operating in the realm of 'state policy'. At first, it seemed shocking to them that foreign policy could be treated like any other public policy area (and thus become subject to the lobbying efforts of interest groups).

In the context of the research questions addressed here, and compared to previous governments, two aspects of foreign policy in the PT years stand out: first, Brazil's 
more assertive stance in trade negotiations; and second, foreign policy-makers' greater openness to domestic political pressures. The two features were inextricably linked in many ways. When Celso Amorim took the lead in shifting Brazilian foreign policy towards a more revisionist and autonomous stance in multilateral institutions, he not only reinforced Brazil's traditional preference for multilateralism, but also set the tone for a new, more inclusive approach to foreign policy. ${ }^{33}$ It should be emphasized that as trade negotiators and business networks worked together to shape Brazilian proposals in the DDR, these were always highly technocratic, but also politically informed, exchanges.

Lula took care to balance ideological preferences with more pragmatic positions. He found business demands for growth-boosting trade policies compatible with his stated commitment to macroeconomic prudence in the pre-2008 period. All the same, and notwithstanding Lula's pragmatic approach to economic issues, Brazil's leadership of the trade G20 at the Cancún ministerial (and later efforts to continue to please its followers ${ }^{34}$ ) came at the cost of re-ideologizing global trade negotiations. Brazil's decision to adopt a more confrontational stance and more distributive negotiating strategy ${ }^{35}$ to support its emerging power partners, such as India, was often welcomed by other societal actors (mainly trade unions and NGOs) that formed important parts of the PT support base. However, this was increasingly criticized by business, especially the competitive agribusiness sector.

These two clashing drivers of PT foreign policy_ideological and pragmatic-could be kept more or less in harness alongside one another as long as the world economy was

33 See Sean Burges, ‘Auto-estima in Brazil: the logic of Lula’s South-South foreign policy’, International Journal 60: 4, 2005, pp. 1133-51; Tullo Vigevani and Haroldo Ramanzini Junior, 'The changing nature of multilateralism and Brazilian foreign policy', International Spectator 45: 4, 2010, pp. 63-71; Matthew Stephen, 'Rising regional powers and international institutions: the foreign policy orientations of India, Brazil and South Africa', Global Society 26: 3, 2012, pp. 289-321.

${ }^{34}$ Doctor, 'Brazil’s role in institutions of global economic governance'.

${ }^{35}$ Andrew Hurrell and Amrita Narlikar, 'A new politics of confrontation: Brazil and India in multilateral trade negotiations' Global Society 20: 4, 2006, pp. 415-33; Amrita Narlikar, New powers: how to become one and how to manage them (London: Hurst, 2010). 
growing and demand for Brazilian goods was booming. When economic conditions changed for the worse from 2008, their discordant goals generated irreconcilable tensions between the state and various societal actors. Even so, the lingering legacy of Lula’s early pragmatic approach could still be seen years later. In 2015, Ambassador Mauro Vieira, Rousseff's second foreign minister and a career diplomat, insisted on the continuing importance of reassuring business that Itamaraty would 'redouble [its] efforts in the area of international trade ... promoting and defending the Brazilian productive sector, assisting it in its own initiatives and helping wherever possible to attract investment'. ${ }^{36}$

As has already been made clear, Itamaraty's interactions with business emphasize the value of technical contributions that help reinforce its foreign policy positions and negotiating strategies. This type of information is of greatest value to diplomats and trade negotiators, because it supports their actions in the international arena. It is well known that Brazilian diplomats favour presenting technically informed and researchbacked positions within institutionalized legal frameworks in the international arena. This is not an unusual preference for a professionalized diplomatic corps, as Allison has pointed out. ${ }^{37}$ However, the costs of generating these high-quality policy materials would be prohibitive without some of the onus falling on those societal actors (businesses) with the most to gain from their deployment. In any case, certain types of information can only be obtained directly from the relevant societal actors - which in the case of trade policy very often (but not exclusively) means business entities. Notwithstanding the apparent greater inclusion of societal input into foreign policy, my research found that Itamaraty still remained relatively distanced from civil society and insulated from day-to-day domestic politics. It had much more control over societal access to, and the nature of societal inputs into, foreign policy decisions than was typical of other policy areas. Also, diplomats often found that they could more easily override the views of other political actors, by virtue of their prestige, their specialist knowledge and the general perception that they were defenders of Brazil's long-term

\footnotetext{
${ }^{36}$ Mauro Vieira, inaugural speech as foreign minister, 2 Jan. 2015, http://www.itamaraty.gov.br/pt-BR/discursos-artigos-e-entrevistas-categoria/ministrodas-relacoes-exteriores-discursos/6398 .

${ }^{37}$ Graham T. Allison, Essence of decision: explaining the Cuban Missile Crisis (Boston: Little, Brown, 1971).
} 
national interest. Thus, Itamaraty got away with consulting societal groups (mainly business) on technical issues, on its own terms, and when it chose to do so-essentially, operating a policy of invited contributions rather than open democratic access (as it still does). This seemed to be accepted not only by business, but also by politicians, the latter seeming persuaded that the executive’s dominance over foreign policy was of benefit to Brazil.

Among the most significant changes to the traditional features and perceptions regarding Itamaraty and foreign policy-making was the ministry’s shift towards working more closely with civil society. With the creation of the SAIA, the split of foreign relations functions between Itamaraty and the new position itself hinted at a greater receptiveness to societal input. For the SAIA, this was indeed the point of the new role, but Itamaraty had to learn to reposition itself in this new political context. Thus, during the PT years, there was a marked increase in societal efforts to influence foreign policy. Whereas initially business relied on traditional elitist channels to communicate with Itamaraty, it soon felt elbowed aside by new voices from civil society. Moreover, the growing relevance of public diplomacy around the world also suggested that Itamaraty needed to become more open to societal views both at home and abroad. ${ }^{38}$

Why, then, did the PT's approach and Itamaraty's response to societal inputs into foreign policy change over the party's 13 years in government? My research showed that the shift in foreign policy-makers' approach to societal inputs can be explained by three key factors: economic conditions, political leadership and societal interest representation. As already mentioned, the point of change seemed to occur immediately after the global financial crisis, rather than simply in response to a change of president (although changes in leadership style and preferences undoubtedly reinforced the shift, as discussed below).

First, the global financial crisis of 2008-2009 left Brazil’s confidence soaring, with a sense that it was less constrained by these events than many other states. ${ }^{39}$ Yet as global economic conditions changed in the aftermath of the crisis, the PT's foreign economic policy preferences and targets also shifted. Whereas in the pre-crisis period Brazil had

\footnotetext{
${ }^{38}$ Milani et al., Atlas of Brazilian foreign policy, pp. 60-61.

39 Joshua Goodman, 'Brazil: the global power looking for a backyard', SAIS Review 29: 2, 2009, pp. 3-10.
} 
proudly proclaimed its universalistic and wide-ranging trade exchanges (divided in roughly equal proportions between Europe, North America, Latin America and the rest of the world), recession in the advanced economies in 2008-2009 pushed the government into prioritizing economic exchanges and development cooperation with the South (especially Asia, but also Africa). Development cooperation brought other civil society actors into the picture, and these became central to Brazil’s growing economic (not necessarily trade) ties with the South. Although business retained a role as an important source of outward investment, the nature of the investment meant that the government switched attention from industrialists to the empreteiras. As noted above, the needs of the former in terms of Itamaraty interaction were very different from those of the latter.

Under Rousseff, domestic economic conditions and policy choices changed markedly. She switched from the prudence-orientated macroeconomic policies of the Lula years to a more sharply developmentalist and state interventionist position. Soon, business was openly criticizing her so-called 'new economic matrix' even as it benefited from the many tax exemptions and subsidies offered. The tense relations between government and business were translated into sharp business criticism of the government's seemingly more isolationist foreign economic policy. Many businesspeople interpreted Rousseff's decision to cancel her state visit to the United States upon revelations of cyber-spying ${ }^{40}$ as a short-sighted political move that ignored important trade and investment interests.

Another key reason for the shift in attitudes towards business/societal inputs was the change in political leadership style between Lula and Rousseff. Generally, the political discourse and foreign policy content of the PT years emphasized voice and inclusion for ordinary citizens (even if only at the rhetorical level). Hence, a greater openness to all societal actors, including business, should have been expected. During the Lula years, the president's personal interest, political style and highly activist foreign policy agenda led to ad hoc but direct interaction between foreign policy-makers and business representatives. Gradually, various steps were taken to formalize societal inputs. This more routinized format better suited Rousseff's policy-making style, but came at the

\footnotetext{
${ }^{40}$ Peter Hakim, 'The future of US-Brazil relations: confrontation, cooperation or detachment?’, International Affairs 90: 5, Sept. 2014, pp. 1161-80.
} 
cost of diluting close ties between business entities and the government's foreign policy agenda.

Whereas Lula adeptly kept business and other societal actors apart in the two-tiered foreign policy-making structure (Itamaraty and SAIA), Rousseff seemed less inclined to do so. When Antonio Patriota, Rousseff's first foreign minister (and a career diplomat), announced the creation of a Civil Society Forum for Foreign Policy in 2013, he thereby gave rise to much disquiet among not only business groups but also his colleagues in Itamaraty. The forum, which seemed designed to exclude business participation, generated considerable interest from trade unions and confederations, such as the Workers' Central Union (CUT) and Union Force (Força Sindical). Patriota was also behind the launch of a series of talks called the dialogue on foreign policy (dialogo sobre politica externa), which aimed to stimulate wider public debate on foreign policy issues. Bringing trade unions and social movements into the corridors of Itamaraty materially and symbolically affected business's privileged position in the foreign policy-making equation. Thus, it was no surprise when business interests started to lash out.

It is worth noting that the foreign policy positions and strategies employed by Brazil during the PT years, based on calls for equity rather than legal and technical criteria, were much against the inclinations of traditionally trained Brazilian diplomats. Equally, diplomats (especially older ones) were often less than comfortable with the growing influence of trade unions, NGOs and other non-elite civil society actors in the realm of foreign policy. It is in this context that many of the most senior diplomats moved from benign tolerance of contacts with business to more overtly welcoming such interaction. The growing participation of civil society in foreign policy debates also created a real dilemma for Itamaraty. Diplomats were often caught between trying to respond to domestic societal pressures (often on economic issues, but also on questions of human rights, the environment, actions in the UN and so on) on the one hand, and attempting to satisfy the expectations of Brazil's followers in the global arena on the other. As noted above, these two imperatives could pull in contradictory policy directions. Moreover, balancing these sometimes incompatible policy aims had to be accomplished without losing sight of what diplomats saw as their prime objective, that is, serving the national interest (however defined).

Unsurprisingly, given the many changes introduced in the PT years, the harshest critics of so called diplomacia lulopetista (a disparaging term for 'Lula-PT diplomacy') were 
often diplomats themselves, along with previous ministers linked to the government of President Fernando Henrique Cardoso (1995-2002). Needless to say, only those already retired from the foreign service could afford to speak openly in criticism of both PT foreign policy and foreign policy-making - and they rarely missed an opportunity to do so, whether in the press or at business and academic conferences. They repeatedly pointed to the PT's 'diplomatic deficit' in the context of the Rousseff government. They loudly lamented that foreign policy remained a very low priority in Rousseff's second government and feared another four lost years to industry. Criticizing the partisan approach to foreign policy, Barbosa wrote that 'PT foreign policy broke with the domestic consensus, because, in many cases, it put aside the defence of permanent principles and the national interest, presenting weak results'. ${ }^{41}$ Meanwhile, Foreign Minister Vieira tried to reassure Brazilian business and promised a more pragmatic approach to foreign policy and a 'results-driven diplomacy' ${ }^{42}$

Paulo Roberto de Almeida is among the most outspoken critics, referring to PT foreign policy as ‘infantile anti-Americanism’ and deriding 'anachronistic anti-imperialism' and 'myopic South-South relations'. ${ }^{43}$ Others were more circumspect in their comments. For example, Barbosa did not stint his criticism of PT foreign policy, but expressed it in much more measured terms. ${ }^{44}$ As a retired diplomat, he focused much of his concern on what he saw as Itamaraty's marginalization and diminishing reputation for professionalism. ${ }^{45}$ Interestingly, most of his speeches or writings were signed off in his

\footnotetext{
${ }^{41}$ Rubens Barbosa, ‘Agenda das relações internacionais em 2015', Estadão, 12 May 2015, http://opiniao.estadao.com.br/noticias/geral,agenda-das-relacoes-internacionaisem-2015,1685634

42 Vieira, inaugural speech.

${ }^{43}$ Paulo Roberto de Almeida, ‘Epitáfio do lulopetismo diplomático’, Estadão, 17 May 2016, http://opiniao.estadao.com.br/noticias/geral,epitafio-do-lulopetismodiplomatico,10000051687 .

${ }^{44}$ Rubens Barbosa has a regular column in the newspaper Estado de São Paulo (and its online version, Estadão), where he routinely commented on PT foreign policy more generally, and trade policy in particular.

${ }^{45}$ Rubens Barbosa, 'Sumiço do Brasil e Itamaraty marginalizado’, Estadão, 25 March 2014, http://opinao.estadao.com.br/noticias/geral,sumico-do-brasil-e-itamaratymarginalizado-imp-,1144733 .
} 
capacity as president of FIESP's trade council, COSCEX. Two former foreign ministers, Rubens Ricupero and Celso Lafer, both associated with the opposition Brazilian Social Democratic Party (PSDB), also lamented the changes in Itamaraty's style and positions, especially the overly politicized preference for South-South cooperation which — in their view_-brought few concrete material gains for Brazil. Others, such as Ambassadors Jose Botafogo Gonçalves and Roberto Abdenur, usually avoided outright political criticisms, but certainly did not have much praise for the PT government's handling of economic relations with important partners, from Argentina to the United States to China. They often couched their comments in references to their personal experience and the expert knowledge they had acquired when serving in the relevant embassies abroad. ${ }^{46}$

To summarize, this section has answered the second research question, discussing the reasons behind the shifts in Brazilian foreign policy in the PT years.

\section{Concluding remarks}

The discussion above has shown the ambiguity of business views with respect to the graduation dilemmas facing the PT governments in Brazil between 2003 and 2016. While they accepted the gradual loss of developing country status resulting from (greatly desired) economic and social progress, they were less willing to support the government's leadership commitments towards its 'followership' in the global South. They believed this was a mistaken strategy based on a flawed proposition (given that graduation implied Brazil would be less and less able to convince others in the global South that it spoke with their interests at heart). Also, Brazil's natural resources and the prowess of its agribusiness meant that it did not share the concerns of many of its emerging power partners (most seriously, diverging from India's positions over agricultural liberalization in the DDR). Similarly, business did not think the economy was in a position to take on the costs of graduation. In their view, Brazil could ill afford the levels of patience and generosity demanded by the PT's chosen strategic partners and developing-country followers. This point was loudly and repeatedly made at the level of regional relations, with some quiet grumbling as well over multilateral agreements signed at the WTO’s Bali ministerial in 2013.

\footnotetext{
${ }^{46}$ See e.g. Roberto Abdenur, 'Para exportar mais, mais politica externa', Folha de São Paulo, 28 Jan. 2015, http://www1.folha.uol.com.br/opiniao/2015/01/1581419 .
} 
The concerns with respect to these first two graduation dilemmas spilled over into the third, namely how to build support for a nationally shared vision of Brazil's role in international affairs. Despite business complaints about PT foreign policy, businesspeople, who had worked more closely with Itamaraty diplomats during the PT years than ever before, were well aware of the challenges that Brazilian diplomats and trade negotiators faced abroad. Therefore, they were more likely to appreciate the value of cooperation between societal actors and foreign policy-makers in achieving the best foreign policy results.

The analysis has also indicated reasons for the shifting influence of different societal actors over the PT years. The level of influence exercised by business was a function of the changing weight that policy-makers assigned to their pragmatic and ideological preferences. In the first half of the PT period, pragmatic concerns, namely economic growth and macroeconomic prudence to boost investor confidence and competitiveness, exercised much influence over state interaction with business. The positive economic impacts of the commodity boom of the century's first decade facilitated the prioritization of such pragmatic considerations. However, after 2008, the tougher global economic context and the increasing international acceptance of state intervention in markets revived the PT's longstanding ideological proclivities in respect of both domestic and foreign policy. The slowdown in the economies of the North justified a turn to the South. In 2009, China for the first time overtook the United States as Brazil's largest trade partner. Then, when Rousseff became president, she faced a more vocal civil society resentful of the privileged status business had enjoyed in foreign policymaking during the Lula years. Gradually, more ideologically defined positions politicized foreign economic policy to the point where the social inclusion rhetoric of the early PT years came to be reflected in reality. Business elites and Itamaraty diplomats felt increasingly alienated from many government and civil society positions. My analysis shows not only that business consistently relied on Itamaraty diplomats to represent its foreign economic policy preferences, but also that it systematically ignored the other option, the SAIA. The PT made a political miscalculation when it blocked business representatives from acting alongside other civil society actors invited to participate in SAIA's initiatives. This exclusion of business proved counterproductive. Business inclusion might have enabled the PT to reinforce support for foreign policy positions that bolstered Brazil's global leadership, while also creating economic opportunities that generated investment and employment. Instead, it met with growing 
hostility, directed in particular at the ideological stance of SAIA, but also at what it saw as a 'politicized' Itamaraty. The evidence shows that business did not so much ignore as actively (and often vocally) oppose this alternative channel for foreign policy interest representation.

This article offers numerous contributions to the debate on Brazil's graduation dilemmas. Analytically, it demonstrates that civil society matters. No future analysis of Brazilian foreign policy will be complete without consideration of how societal actors feature as a key determinant of foreign policy-making. It adds breadth and nuance to Amorim and Malamud's research discussing foreign policy in Latin America.

Moreover, it refines understanding of the challenges of graduation as matters not just of foreign policy, but of domestic policy too. Empirically, it shows the growing numbers involved in foreign policy-making on both the supply (state actors) and the demand (societal actors) side of the process. The article provides detailed information for a key emerging power, Brazil. It applies Keohane and Milner's insights to examination of the effects of internationalization and structural transformation of the economy on the attitudes and behaviour of domestic societal actors. The analysis shows how important it is to actively engage domestic economic actors and seek their support for government goals and ambitions-not least because state activism in global governance arenas often relies on societal actors' technical inputs and political support.

To conclude, the analysis has clearly demonstrated how business interaction with Itamaraty in the PT years was divided into two phases. At first, it proved much more productive than could have been predicted. In fact, relations between business and Itamaraty were characterized by constructive engagement on both sides, directly contributing to Brazil's rising influence in the DDR/WTO as well as influencing some of Brazil's most successful foreign policy initiatives. Further evidence of the close partnership between business and the PT (especially on matters of trade policy) is provided by the fact that the presidents of both the CNI (Armando Monteiro) and CNA (Katia Abreu) became ministers in PT governments, notwithstanding any ideological differences. In fact, Abreu was one of Rousseff's staunchest supporters during the impeachment process in the Senate.

Eventually, after years of stagnating investment, declining competitiveness and ultimately economic recession, business definitively turned away from the PT. Interestingly, the area where they had worked most successfully together also became the site of the harshest business criticism of the PT: its foreign economic relations and 
trade policy. Also, Rousseff's inability to balance different societal actors’ foreign policy interests and her difficulty in reconciling pragmatic with ideological preferences put Itamaraty in an untenable position, complicating its efforts to defend Brazil's national interest. Moreover, the political tug-of-war between the PT and the opposition over Brazil's foreign policy direction made any serious debate about resolving Brazil's graduation dilemmas futile.

Thus, unsurprisingly, many of the critics of PT foreign policy celebrated when interim President Michel Temer appointed José Serra as foreign minister in May 2016. They believed a politically strong foreign minister and a 'turbo-charged' Itamaraty would focus on rebooting Brazil's trade relations to bring them more in line with the stated preferences of business. ${ }^{47}$ They also expected Itamaraty to recover its influence and role at the centre of foreign policy-making. When Serra resigned owing to health problems in February 2017, his agenda was taken over by his successor, Senator Aloysio Nunes, another experienced PSDB politician who had been chair of the Senate Foreign and National Defence Affairs Committee. While it is reasonable to expect the new government to succeed in prioritizing trade, it will not manage to exclude other societal actors, specifically the trade unions and social movements, who were encouraged to voice their foreign policy preferences during the PT era. Moreover, Itamaraty will have to focus much of its efforts on re-establishing Brazil's and its own image abroad-in both the North and the South—in the aftermath of economic crisis, corruption scandals and a controversial impeachment. To accomplish this, diplomats will need all the political support and societal help they can get.

\footnotetext{
${ }^{47}$ See the 'new foreign policy guidelines' outlined in Foreign Minister José Serra’s speech upon taking office, 18 May 2016, http://www.itamaraty.gov.br/pt-BR/discursosartigos-e-entrevistas-categoria/ministro-das-relacoes-exteriores-discursos/14038; also, Marcos Troyjo, 'Os prós e contras de um Itamaraty turbindo', Folha de Sao Paulo, 4 May 2016, http://www1.folha.uol.com.br/colunas/marcostroyjo/2016/05/1767453-ospros-e-contras-de-um-itamaraty-turbinado.shtml .
} 